Hard ticks show a wide range of adaptability to thoir hosts, ranging from species which are confined to one host to those which show little or no preference for hosts above and including reptiles ${ }^{3}$. Several workers, notably Hoogstraal $^{1}$, Arthur ${ }^{2,3}$ and Theiler ${ }^{4}$, have stated that the blue tick is a one-host tick. Matthyse ${ }^{5}$ has reported that all the parasitic stages of the blue tick occur on cattlo throughout the year. Thoiler' confirmed that the life-cycle of this tick species was completed entirely on this host, except for oviposition. Lewis ${ }^{7}$ has also stated that the blue tick completes its life-cycle as a one-host tick. Finally, Loundsbury ${ }^{8}$ has recorded that the engorged females detach in 23 days after attaching as larvae. In regard to this particular behaviour of the blue tick as a one-host tick species on the ox, my experience is quite the same as that of the aforementioned authors. However, this communication does seem to reporl for the first time the occurrence within the genus of a remarkable departure from this typical behaviour: namely, the peculiar bohaviour of $B$. decoloratus as a two-host tick species. Hitherto all the three members of the genus ( $B$. decoloratus, $B$. annulatus and $B$. microplus) have been described as being characteristically one-host tick spccies ${ }^{1-3}$.

On account of this peculiar bohaviour of some individuals of the blue tick, it is inferred that instoad of transforming into adults at the sites already selected by the larvae, some engorged nymphs of this tick species detachod, wandered about for some time and dropped of eventually to moult into adults. If the nymphs had had opportunity to moult in sheltered areas in the immediate natural environment of the calf, the resulting adults would no doubt have sought the host a second time in order to foed.

I thank the Ghana Acadomy of Sciences for the opportunity and facilities to carry out this work at the Animal Research Institute.

Animal Research Institute,

Ghana Academy of Sciences, Achimota, Ghana.

'Hoogstraal, H., African Ixodoidea. Ticks of the Sudan, 1, 1 (1956).

${ }^{2}$ Arthur, D. R., Ticks. A Monograph of the Ixodoidea. Pt. V. 1, 250 (Cam bridge University Press, 1960).

- Arthur, D. R., Ticks and Disease, 1, 445 (Pergamon Press, London, 1962).

- Theiler, G., Project S, 9958. Report to the Director of Veterinary Services, Onderstepoort (1962).

- Matthyse, J. G., Report on Tick-borne Diseases, 1 (Government Printer, Lusaka, Northern Rhodesia, 1954).

- Theller, A., Agric. J. Un. S. Afr., 1 (4), 491 (1911). In Hoogstraal, H.,

'Lewis, E. A., Empire J. Exp. Agric., 7 (28), 290 (1939).

' Ioundsbury, C. P., Rep. Brit. Assoc. Adv. Sci. Section D., S. Afr., 1 (1905). In Ioogstraal, H., African Ixodoidea. Ticks of the Sudan, 1, 1 (1958).

\section{A Method of Isolating and Counting Nippostrongylus brasiliensis from Unweaned Rats}

Metrods for the recovery and counting of adult Nippostrongylus brasiliensis from the intestines of adult rats have been described by Jennings et al. ${ }^{1}$ and Ogilvie ${ }^{2}$. Such methods need to be very accurnte, particularly where estimations of the degreo of immunity of the host are to bo made on the basis of such counts. The techniques described by these authors have been used routinely in this laboratory during experiments on adult rats and have proved quite satisfactory. However, on application to the recovery of worms from the intestines of neonatal or unweaned rats a number of difficulties were encountered.

Becauso of their small size and delicate structure, oponing the intestines of very young rats with scissors is an extremely difficult procedure and can result in $\mathrm{t}$ signifi. cant loss of worms. The consequent spread of intestinal contents around the site, on instruments, etc., requires repeated rinsing for the recovery of worms, so that they are eventually collected together for counting in an exces- sive quantity of fluid. Such a method is particularly unsatisfactory during the early stages of an infection when immature forms, not visible to tho naked oye, are present. These difficulties are eliminated in the method described here.

The abdomen is opened and the posterior ocsophagus cut; the stomach is then loosened from its surrounding attachments and the small intestine gently unravolled, particular care being taken in the region of the pancreas and caecum, where tho intestine is most likely to broak. It is then threaded on to a glass rod of $5 \mathrm{~mm}$ diameter, one end of which has been drawn out and the tip heated to a ball of such size that it easily enters the lumen of the intestine. The whole small intestine splits opon during this procodure, and it is then transferrod to a 1-l. beaker containing $\mathrm{N}$ saline at $37^{\circ} \mathrm{C}$. The gloved fingers of the operator and the glass rod are rinsed with saline into the sime beaker, until no traces of intestinal contonts remain. The contents of the beaker are then drained through a double layer of surgical gauze spread over the top of a socond boaker so that the intestino is rotained in the gauze. The first beaker is repeatedly rinsed into the second. The gauze is then eaught up on a glass rod so that the intestine is suspended in the saline. The beaker is left in a water bath at $37^{\circ} \mathrm{C}$ for $1 \mathrm{~h}$, by which time the worms have penetrated the gauze and are lying at the bottom of the beaker, in 500 to $1,000 \mathrm{ml}$, of saline.

The contents of the beaker are filtered through a Büchner funnel using Groen's 'Hyduro 904', $18.5 \mathrm{~cm}$ diarm. filter paper, which has been previously marked off in $8 \mathrm{~mm}$ squares on a duplicating machine, with repeated rinsing to ensure that all the worms are transferred from the beaker to the filter paper. By adjusting the flow from the beaker the worms are spread evenly over all but the periphery of the filter papor.

The filter paper is removed and, if the worms are required only for counting, is allowed to dry completely. The worms are easily visiblo as red coils adhering closely to the paper, and aro counted at a magnification of $12.5 \times$ using a binocular microscope. The 8-mm squares on the filter paper act as conveniont guidelines.

If the worms are required alive, the filter paper, while still wet, is laid for counting on a sheet of 'Porspox' $20 \mathrm{~cm}$ in diameter. Afterwards tho filter paper is inverted over a $1 / 16$ th in. mesh sieve on top of a filter funnel containing normal saline at $37^{\circ} \mathrm{C}$ and fitted with a tap. The worms descend through the saline and collcet in the narrow stem above the tap, from where they can be run off into a stoppered measuring cylinder to the required dilution.

\section{PaUL WhUR}

Maky Gracie

Department of Veterinary Histology and Embryology,

University of Glasgow.

1 Jennings, F. W., Mulligan, W., and Urquhart, G. M., Exp. Parasit., 18, 367 (1963).

Ogilvie, B. M., thesis, Univ. Cambridge (1963).

\section{A Periodicity of Tritiated-thymidine Incorporation into Cytoplasmic Deoxy- ribonucleic Acid during the Cell Cycle of Tetrahymena Pyriformis}

RFPonts indicato that ${ }^{3} \mathrm{H}$-thymidine is incorporated into a DNase-sensitive material in the cytoplasm of the ciliate Tetrahymena pyriformis ${ }^{1-5}$. It is now known that most of this cytoplasmic DNA is localized inside the mitochondria of this species ${ }^{1}$. Furthermore, this cytoplasmic DNA appears to bo stable and conserved during cell growth and reproduction ${ }^{1,4}$.

The purpose of this communieation is to establish whether or not a relationship exists between cytoplasmic DNA replication and the DNA replication in the micro- or macro-nucleus of the cell. 'I'etrahymena pyriformis strain 